\title{
Methodological aspects of saving of the core national wealth of Ukraine
}

\author{
I. Novakovska, \\ doctor of economic sciences \\ National aviation uneversity
}

The purpose. To investigate trends of dynamics of land-use and some kinds of lands for years of land reform, their influence on structure of land reserves and land organization, to consider main routes and methodological approaches to protection lands as to the basic national wealth of the country. Methods. Analysis and synthesis, abstract-logical, system generalization. Results. Prime measures which realization can ensure balanced use, ecologization and protection of agricultural lands are offered. Conclusions. The working system of compensation of losses of agricultural and forest industry, caused by withdrawal of lands, does not ensure economic protection of lands and should be improved. With that purpose it is necessary to develop the Law on the nation-wide program of use and protection of lands, to elaborate design of schemes of land organization of territorial communities, to create national fund of support of land-use.

Key words: land-resource potential, economical land-use, economic protection of lands, protection of land resources.

The Constitution of Ukraine, taking into account, has established the extremely important importance of land in all spheres of life and said that "land is the main national wealth that is under special protection of the state". [2, art. 14].

The land reform, which has been begining on March 15, 1991, was aimed at redistributing land in order to create conditions for the equal development of a multi-faceted economy, rational use and protection of land. During the period of the reform, the state monopoly was liquidated, land privatization was established and private land ownership was formed, the existing structure of agricultural production was reformed, new agricultural structures were created, land plots were introduced, the system of market land legislation was mostly established, the land market began to operate. However, one of the main tasks of land reform is the rational use of land that is implemented too slowly, and the protection of land fund is unsatisfactory [7].

Negative processes that take place regarding the dynamics of land use and land in the process of reforming land relations are not sufficiently covered in scientific and special literature. Issues of the organization of the state land cadastre, the formation of the market of agricultural land, the development of lease relations on a competitive basis prevail among publications of land resources authorities and scientists. Due to the demographic crisis, which resulted in the reduction of the number of not only rural population, but also the urban population, the temporary occupation of the territory of the Autonomous Republic of Crimea and the conduct of antiterrorist operations on part of the territory of the eastern regions of the country, the issue of economical use and protection of land and conservation of land productivity are considered less relevant.

Conservation of agricultural land and resource potential of the country in modern conditions, when large areas of productive lands are lost, and the needs for food for the society are constantly growing, it is necessary to develop a scientific forecast of the dynamics of land use and measures to balance it, the interference of state bodies to ensure the continuous protection of the land fund, the organization ecologically safe land use [10]. 
It is well-known that Ukraine has unique land-resource potential, economical, efficient, rational and environmentally safe use and protection in the current conditions is one of the most urgent problems of national security of the state.

By occupying the third place among the countries in the area of arable land per capita, our state has the ability to meet the needs of food at least 180 million people in case of efficient use of land. Black soils of our country make up $8.7 \%$ of the area of black soils all over the world and occupy $2 / 3$ of the total area of agricultural land of the country. Ukraine's land resources are playing a prominent role in supplying food, and this role will continue to grow in the future for our state and for the world community [6].

Land impartiality for a person, territorial limitations (in size), location are distinguished land from other natural objects and, although it relates to real estate, that is the material basis without the initial value, can not be the ordinary property that is in civil law. Land is the main national wealth of the country. So that is the main Difference of land from another property. [5]

The constitutional principle of special protection of lands as national treasures is aimed at preventing the unjustified removal of agricultural land as the main means of production in agriculture, the rational use of land, protection of land from harmful anthropogenic influences, reproduction and increase of soil fertility, and ensuring a special regime for the use of especially valuable land. However, this principle has not always been respected during land reform in a country that has been continuing for 26 years. Increasing the level of forest cover and reducing agricultural development and land cultivation should not be considered only as a consequence of the widespread implementation of environmental safety requirements during the years of land reform. Agricultural land had been used for non-agricultural needs, in particular, for expanding the area of settlements, for housing development around regional centers and medium-sized cities, led to the loss of the share of land with especially valuable soils. The carve-up of land has led to a breach of crop rotation and contour-melioration of the land as a framework for scientifically grounded farming that was formed.

The area of the cities and towns of urban type has grown on 703 thousand hectares as a result of the land reform. The area of built-up land has increased by almost 400 thousand hectares. The land of cities and towns particularly has been grown in the first five land reform years, when more than 0.5 million hectares of nearby territories were included in the cities and villages (Table 1).

Table 1. The dynamics of land in Ukraine in 1991-2016 timeframe [5].

\begin{tabular}{|c|c|c|c|c|c|c|c|c|}
\hline \multirow{2}{*}{$\begin{array}{l}\text { № } \\
\text { n/o }\end{array}$} & \multirow[b]{2}{*}{ Types of land } & \multicolumn{6}{|c|}{ Land area, thous. ha by year } & Changes \\
\hline & & 1991 & 1996 & 2000 & 2005 & 2011 & 2016 & $\begin{array}{l}\text { for } 1991- \\
2016 \text { years }\end{array}$ \\
\hline \multirow[t]{2}{*}{1} & $\begin{array}{l}\text { Agricultural } \\
\text { land }\end{array}$ & 42030,3 & 41852,9 & 41829,5 & 41763,8 & 41576,0 & 41507,9 & $-522,4$ \\
\hline & $\begin{array}{|ll|}\text { They } & \text { are } \\
\text { arable } & \end{array}$ & 33571,1 & 33286,2 & 32669,9 & 32482,2 & 32476,5 & 32541,3 & $-1029,8$ \\
\hline 2 & $\begin{array}{lr}\text { Forests } & \text { and } \\
\text { other forests } \\
\text { area }\end{array}$ & 10221,3 & 10375,8 & 10403,3 & 10475,9 & 10601,1 & 10633,1 & $+411,8$ \\
\hline 3 & built-up land & 2161,1 & 2313,1 & 2457,4 & 2458,3 & 2512,5 & 2552,9 & $+391,8$ \\
\hline 4 & Open wetlands & 884,0 & 934,9 & 946,0 & 957,1 & 979,9 & 982,3 & $+98,3$ \\
\hline 5 & Water & 2435,1 & 2418,6 & 2426,2 & 2421,1 & 2423,5 & 2426,4 & $-8,7$ \\
\hline 6 & Land of cities & & & 1261,3 & 1296,4 & 1322,7 & $1341,9^{*}$ & \\
\hline 7 & $\begin{array}{l}\text { The lands of } \\
\text { the settlements }\end{array}$ & 1201,4 & 1712,5 & 522,2 & 537,5 & 560,7 & 562,9 & $+703,4^{* \star}$ \\
\hline
\end{tabular}

This information has been calculated according to the data of the State Committee for Land

Resources, the State Land Agency and the State Geodetic Committee for the relevant years.

Note: data on the area of cities and towns in $2015^{*}$, and on areas changing for 1991-2015 years** 
Permanent growth of areas of settlements is not directly relating to the dynamics of population. Demographic crisis has been caused by the socio-economic and demographic policies of the state, only for 1996-2016 years the number of urban residents decreased by 5.1 million people. The general population density has decreased from 86.3 to 74.4 persons per $1 \mathrm{~km} 2$ (excluding the temporarily occupied territory of the Autonomous Republic of Crimea). The cities of Dnipro and Donetsk have moved from the group of the largest (more than 1 million people) to a group of large cities (from 0.5 to 1 million people), and the cities of Mykolaiv and Mariupol from large cities became large cities (population from 0.25 to 0.5 million people).

When Ukraine became independent in 1991, so in this period state was characterized by a rather high level of urbanization - $67.8 \%$ [5]. Our country was a part of the twelve countries of Europe in an average population density in this period of time. It should be noted that $4 / 5$ of the urban population of the country had been living in the most significant (more than 1 million people) and large (from 500 thousand to 1 million people) cities. The total population of the five most important cities (Kyiv, Kharkiv, Dnipropetrovsk, Odessa, Donetsk) was 7.6 million people or $31.6 \%$ of the total urban population. The rate of urban land use efficiency compared with the corresponding classification groups of European cities was 1.5-2.0, and in some cases and 3-5 times lower despite the high average urbanization. The occupation of a large part of the city territory by land for the maintenance of a personal auxiliary farm, the organization of gardening, the implementation of dwelling-house building with private plots, was caused the dispersal of urban development and excessive, inefficient use of the territory of cities and urban-type settlements.

The total area of agricultural was decreased by 522 thousand hectares that isexplained by the transfer of part of the unproductive and degraded lands under flood. This result will promote the environmentalization of land use, in particular, the optimization of the land parcels ratio. However, the reduction of almost 1030 thousand hectares of arable land in 1991-2016 is difficult to justify, but it is not possible to justify it at all. The arable land was deduced from the turnover that is. equal to the size of the arable land of Lviv and Zakarpattya region. To a large extent, the dynamics of changes arable land over the years of reforming land relations is spontaneity of the implementation of land reform measures. Land reform programs in the country were not developed. The instruction to the Government, regional councils to develop and approve state and regional (city) land reform programs, that was adopted by the Verkhovna Rada of Ukraine in March 1992 in connection with the introduction of private ownership of land, were not done. The main directions of the reform for 2001-2005, approved by the

Decree of the President of Ukraine on May 30, 2001, are not implemented in an absolute majority also [4].

Implementing measures of land reform, the development of comprehensive land-use documentation at the state and regional levels was stopped: a general scheme of land management, schemes of land management of oblasts and administrative districts, which did not allow solving on a scientific level problems of redistribution of land, privatization of land, protection of land resources . Over 5 million hectares of unproductive and degraded land, primarily arable, instead of conservation, the transfer to natural forage or afforestation was decomposed, which was made it difficult to protect them from degradation processes. The growth of the territories of settlements was carried out in the absence of general plans for their development, without proper justification, only on the basis of schemes of establishing the boundaries of local councils, villages, settlements, cities. Public authorities have lost land reform management functions that was caused violations of ecologically sustainable agricultural land use and formed his grinding, cessation of works to combat soil erosion.

Land management documentation, that was compiled in the course of reforming land relations, was mainly local, and it had one purpose this is the boundary of the land fund, and not rational organization and the creation of conditions for compliance with environmental safety requirements. During the time of the reform, the development of not only forecast (pre-design) and planning, but also many types of design, work and technical documentation on land management has significantly decreased or stopped at all. Ukraine does not have the updated information base on land for solving modern problems of ensuring the rational use of land resources of the country and their protection, regulation of land relations, guaranteeing rights to land of citizens, legal entities, territorial communities and the state. 
The territory of the oblast, district, the local Council do not have the appropriate up-to-date land use, urban planning, environmental, and other materials. There are not general plans, plans for the landeconomic arrangement, detailed plans and plans for zoning the territory of cities for the absolute majority of settlements.

The system of compensation for agricultural production losses associated with land withdrawal, was changed in 1997, and now it does not correspond to the level of modern monetary valuation of agricultural land [4]. Losses are extremely understated, so that should not be comparable to the factor of economic appraisal of the impact of seizure of land plots, as well as restrictions on land use, land servitude. List of works is constantly expanding, that is using money, which are received in the order of compensation of losses of agricultural production. Under the current Land Code (Article 209), these works are even conducted inventory of land, demarcation of lands of state and communal property, which are not directly related to the development of new lands, and to increase the fertility of soils, productivity of forests, improvement and protection of lands. This leads to an unjustified reduction in the amount of funds that must be used to restore the agricultural potential of the country [1].

In comparison with the decree of the Cabinet of Ministers of Ukraine of 17.11.1997 № 1279, in recent years the list of citizens and legal entities exempted from indemnification of losses has been expanded. In particular, they identify wholesale markets for agricultural products, energy objects that produce electricity from alternative sources, and peat enterprises. The lawfulness of referring them to this category is rather dubious [8].

Agricultural production also suffers significant losses due to the legal uncertainty of the amount of funds caused by restrictions on agricultural land use in security and sanitary protection zones, in sanitary protection zones and in particular land use regimes, as well as in the reduction of land quality during the construction of facilities and the extraction of fossil fuels. If agricultural land users were compensated for losses related to land use restrictions and land degradation, as stipulated by law, the proceeds from expert calculations would be higher by $6-10 \%$ of gross crop production.

Significant disadvantages associated with the precarious use of land during their redistribution, in particular due to the occupation of large areas of agricultural land for non-agricultural purposes, ignoring the requirements of the state authorities regarding the need for special protection of land funds, are conditioned, first of all, by the lack of long-term land use and protection programs at the national level and regional levels. Since January 1, 2002, when the current Land Code came into force, the National Program for Land Use and Protection has not been drafted and approved by the time. The use and protection of other natural resources of the country (forests, waters, subsoil, air, etc.) are regulated by the relevant programs. According to the Constitution of Ukraine, the land is recognized as the main national wealth that is under the special protection of the state. Unfortunately, our countru does not have land protection programs. The state budget almost does not provide funds for the implementation of land conservation and land productivity, soil fertility is constantly decreasing [3]. The terms were established by the normative and legal acts regarding the submission of this Program for approval by the Verkhovna Rada of Ukraine were violated five times, in the draft resolution of the Verkhovna Rada of 27.03.2017, No. 6241, on recommendations of parliamentary hearings concerning the circulation of agricultural land with the Cabinet of Ministers This question no longer contains specific terms. A similar situation exists with regard to state programs for improving soil fertility and land development, which have been developed but have not been approved [9].

A significant amount of work on the formation of united territorial communities has already been implemented, but land management projects for establishing their boundaries have not been developed for any one community. So the land management system does not fulfill its functions in the state. The land cadastre does not contain information on especially valuable lands, does not inform the population and authorities about the negative processes of the dynamics of land plots that take place. Funds from land use fees (land tax, rent, costs from agricultural and forestry losses) are not properly used to support land resource potential of a country, preservation of valuable land and increase the efficiency of land use. 


\section{Conclusions}

Unique land-resource potential of Ukraine, in accordance with the constitutional provisions, requires special state protection. The constitutional principle of protecting the land as the main national wealth involves, in the first place, the prevention of unjustified reduction of the agricultural area ensuring their rational use and protection. The lack of land reform programs at both national and regional levels, the lack of management of land reform processes, and the disregard of requirements for forecasting and land use planning with the necessary land use documentation during the reform led to a significant reduction in the area of arable land, a violation of the formed skeleton contour- reclamation agriculture, loss of crop rotation. Significant areas of land are occupied for the expansion of territories of cities, villages, rural settlements, built cottage towns, private health institutions, including land with especially valuable soils. Of the agricultural turnover over the years of the reform, 1030 thousand hectares of arable land were harvested, equal to the arable land of Lviv and Zakarpattia regions taken together. In fact, the work on the protection of land has ceased, and the state budget does not provide the necessary funds for these measures.

Until now, National Program for Land Use and Protection, soil fertility conservation, land relations development in the state was not written, forecasting and land use planning was abandoned.

Preservation of the main national wealth of the state necessitates the development and implementation of a complex of measures at the national, regional and local levels, the main of which are the following:

a) drafting and submitting to the Verkhovna Rada of Ukraine a draft Law of Ukraine on a national program of land use and protection for 2018-2015, preparation on the basis of this Program of the relevant regulatory and legal acts on implementation of the problems of rational use and protection of land;

b) the development of a state program for the protection of soil fertility for agricultural purposes for 2018-2030, its approval by the Cabinet of Ministers of Ukraine and the drawing up of road maps for the implementation of its activities by region and period;

c) ensuring the development of schemes of land management of the combined territorial communities, the formation of which is continued in order to carry out these works to gradually and timely create conditions for the effective use, ecologization and protection of agricultural lands and agro-landscapes;

d) solving problems of land management, land cadastre, financing of land protection measures, land use control, which arose from the introduction of market land relations and complicated land use management processes in the country.

\section{Bibliography}

1. Land Code of Ukraine dated October 25, 2001, No. 2768- III / Відомості of the Verkhovna Rada of Ukraine. -2002. № 3-4. - Article 27

2. The Constitution of Ukraine dated June 28, 1996 No. 254k / 96-VR / Information from the Verkhovna Rada of Ukraine. - 1996. - №30. - Art. 141

3. National report on completing the land reform / in the sciences. Ed. L.Ya.Novakovskii - K .: Agrarian Science, 2015. - 48s.

4. Novakovskaya I.O. Fundamentals of land use economics: [monograph] / IO Novakovskaya - K .: Prosvita, 2013. - 224 pp.

5. Novakovskaya I.O. Urban Land Management: [monograph] / IO Novakovskaya - K .: Agrar. science, 2016. - $304 \mathrm{pp}$.

6. Novakovskii L.Ya. Land - the main wealth of the Ukrainian people / Land Management Directory [ed. L.Ya.Novakovskii] .- 4th species., Processing. and add - K .: Agrar. science, 2015. - 492p.

7. Novakovskii L., Budzlovich I. Lessons of Land Reform. - K.: Harvest, 2002. - 128 p. 
8. On the size and Procedure for determining losses of agricultural and forestry production, which are subject to reimbursement: Resolution of the Cabinet of Ministers of Ukraine of November 17, 1997 № 1279 // Official bulletin of Ukraine - 1997, no. 47, p. 40

9. About the Recommendation of the Parliamentary Hearings on the topic: "Regulation of the Turnaround of Agricultural Land: Search for a Ukrainian Model": Draft Resolution of the Verkhovna Rada of Ukraine // [Electronic resource] / Access mode http://search.ligazakon.ua/l_doc2.nsf/link1 DH4TD00A.html

10. Socio-economic potential of sustainable development of Ukraine and its regions: national report / ed. acad. NAS of Ukraine E.M. Libanova, acad. NAAS of Ukraine M.A. Hwsika - K .: DU IEPPS NAS of Ukraine, 2014 - $776 \mathrm{p}$. 